\title{
Design of an Arabic Spell Checker Font for Enhancing Writing Skills: A Self-learning Prototype Among Non-Arabic Speakers*
}

\author{
Muhammad Sabri Sahrir \\ International Islamic University Malaysia, Kuala Lumpur, Malaysia
}

\begin{abstract}
The use of modern technology in the process of teaching and learning the Arabic language has a very important role in developing students' performance and improving their listening, speaking, reading, and writing skills. Students of non-native Arabic speakers are in the high need of using modern technology in language learning, which contributes to the development of the four basic language skills, since they are living outside from the original Arabic environment. This technology contributes to the creation of an artificial environment to learn a second language (L2) among them. With regard to the process of learning the Arabic language by using modern technology in Malaysia, it has attracted academic discussions of research by various researchers and experts in this area, such as the lack of utilization of Arabic language teachers for modern instructional technology and the lack of creating innovative technology in teaching the Arabic language. However, it is found that there are several attempts to invent modern technologies in teaching the Arabic language in Malaysia, such as the design of computer language games in learning Arabic, the use of e-portfolio in Arabic language learning, and virtual tutor. Consequently, this research seeks to study the possibility of designing and developing a prototype that specializes in improving the writing skills in the Arabic language for non-native speakers through a program that is considered as flexible and interactive. The program is expected to enhance learners' self-motivation and improve their language skills by self-monitoring in common writing errors by Malaysian students. The design of such an interactive program aims to develop Arabic writing skills and eventually to evaluate this program among students for further improvement in the future. This program is specifically designed to identify and correct morphological errors by using the Microsoft Word program via a special font known as "Modaqqeeq Sarfiy" (morphological checker). This research is following design phases of the ADDIE (i.e., Analysis, Design, Development, Implement, and Evaluate) instructional design model in the design and development of this prototype among students taking a course for computer applications in International Islamic University Malaysia (IIUM). The result of this study has indicated high mean scores among the students towards this interactive spell checker, in addition to suggestions and comments for further improvement. This research has definitely stressed on the importance of using advanced and new emerging technologies as a means to enhance the teaching and learning of the Arabic language to non-native speakers.
\end{abstract}

Keywords: learning Arabic, writing skill, designing programme, self-learning, formative evaluation

\footnotetext{
* Acknowledgement: This research project is funded by the Research Management Centre (RMC), International Islamic University Malaysia (IIUM) under Research Endowment Type B, July 2013-November 2014. Title of the project: Designing Arabic Interactive Courseware for Enhancing Writing Skills: Self-Learning Prototype Among Non-Arabic Speakers in IIUM (MYR 20,000). Project ID: EDW B13-056-0941.

Muhammad Sabri Sahrir, Ph.D., assistant professor, Kulliyyah of Islamic Revealed Knowledge and Human Sciences, International Islamic University Malaysia.
} 


\section{Introduction}

Teaching Arabic as a second language (L2) in Malaysia has become popular due to the importance of this language that it has been used as a medium of instruction in teaching Islam and its knowledge. According to Tu'aimah (1989), learning a foreign language means that "An individual is be able to use the language, including comprehend, communicate, and write as he/she does in his/her first language". He further explained that learning Arabic as a L2 must accomplish two levels of learning process: (a) acceptance of the language; and (b) the use of this language. The significance of language utility was also discussed by Bygate (1987) when he reminded teachers and educators to understand the goal of foreign language teaching and to initiate the effort of preparing the subjects to achieve the desired goal as he said that "One of the basic problems in foreign language teaching is to prepare learners to be able to use the language" (p. 3). On the other hand, several studies have indicated that teaching Arabic as a second or foreign language is not isolated from teaching basic language skills which are listening, speaking, reading, and writing, as stated by Tu'aimah (1989), El-Khuliy (2004), Ahmed Mukhtar (2006), and Abdul Bari (2010). Furthermore, the most challenging skill of those skills is writing skill, which requires higher thinking process and complex capability, including organizing of thoughts and ideas, composing sentences, and then retaining those thoughts on paper as explained by Abdul Bari (2010). The importance of Arabic writing skill acquisition is also discussed by many scholars, and they agreed that written expression is the ultimate goal of teaching Arabic to non-native speakers and the mastery of writing in L2 is considered as a significant achievement of measuring individuals' language proficiency (El-Khuliy, 2004; Majdi \& Rosli, 2011; Tinggari, 2011).

\section{Computer-Assisted Language in Teaching and Learning Arabic}

The development of teaching methods in the field of foreign language teaching, especially in teaching Arabic as a L2, has recently become a topical discussion among scholars and teachers. The major cause for being that is the emergence of new technologies and the challenging of the Arabic language itself (Nashwan, 1993; Ahmed Mukhtar \& Mohd Feham, 2007). Moreover, selection of teaching tools plays an important role in transmitting knowledge and skills to learners. Many scholars believed that the use of computer technology is an important integral tool in the foreign language teaching field, which can benefit to both students and teachers (Ribhi \& Abdel el-Dabbas, 2003; Ahmed Mukhtar, 2006; Nurkhamimi, 2009; Osman, 2009). Nurkhamimi (2009), for example, discovered that Wiki helps in facilitating the acquisition of writing skills among the non-Arabic students from the Department of Economics in Center for Foundation Studies, International Islamic University Malaysia (IIUM), particularly in assisting them in generating their ideas during the initial phase of acquiring writing skills. He also found that using Wiki as a tool can enhance the Arabic writing skills as students are found to be highly motivated and engaged in the learning process which in turn contributes positively to their learning outcomes. Another attempt is by Ahmad, Rusli, and Mat Daud (2011), who claimed that Internet, i.e., FaceBook, can develop students' writing skills, and they found that the majority of students preferred using FaceBook to enhance their Arabic writing skills. The utilization of these technologies is also supported by Md. Saad, Ismail, and Wan Abdullah (2005), who stressed the need of using new technologies in the foreign language teaching field in Malaysia to achieve the desired learning objectives. They suggested teachers and educators, especially those who teach Arabic as a L2, exploit the electronic tools and educational Websites that are appropriate with the learning environment in Malaysia to enhance or replace their traditional teaching 
methods. However, lack of using computer-assisted technology in the Arabic language classrooms was discussed by Mohd Feham and Isarji (2000), Aladdin, Hamat, and Yusof (2004), Mohd Feham (2006), and Zawawi (2008). Mohd Feham (2006) further indicated that there have been fewer inventions and innovations in the field of Arabic language learning and several reasons have limited the numbers of educational software and courseware in the Arabic language. A majority of Arabic language teachers were found incompetent in using computer and courseware in the teaching process due to poor computer literacy especially among the veteran generations (Zawawi, 2008) and lack of computer training (Aladdin et al., 2004). Furthermore, there is a difficulty to find the Arabic courseware (Mohd Feham \& Isarji, 2000; Mohd Feham, 2006; Zawawi, 2008). Thus, the development of technological production of machinery for Arabic language teaching and learning is very important as it is currently dominated by the American English language, whether it is software or hardware (Wahba, Taha, \& England, 2006). In the application of Arabic computer-assisted language learning, especially in Malaysia, there are several research attempts that are trying to integrate the teaching of Arabic language with ICT, such as using pedagogical agents (Mohd Feham, 2006), online games (Sahrir \& Nor Aziah, 2011; Sahrir \& Ghazali, 2012), teaching writing skills via Wiki (Nurkhamimi, Mohd Feham, \& Sahrir, 2011), and virtual tutor in learning Arabic (Mahmoud, Sahrir, \& Osman, 2013).

\section{Challenges of Teaching Arabic Writing Skills Among Non-native Speakers}

Malay students who learn Arabic as a L2 appeared to have many problems and challenges when writing in Arabic (Rosli, 2007; Abdel Halim \& Muhd Harun, 2011; Samah, 2012). These studies also revealed that challenges in Arabic writing were caused by various factors, i.e., deficiency of vocabularies, composition of multiple sentences, words choice, and grammatical errors (Samah, 2012). Abdel Halim and Muhd Harun (2011) in their studies also identified that the biggest problems faced by Malaysian students in local universities, from teacher's point of view, are students reading few books and Arabic references, less of writing exercises, followed by literal translation from Malay language to the target language, inappropriate use of Arabic preposition, repetition of unnecessary nouns and pronouns, and lack of balance in using nominal phrase and verb phrase, which still remain occurred when writing in Arabic at higher learning institutions (Rosli, 2007). This fact may due to many aspects include subjects, methodology, and strategies of teaching Arabic, as well as experience, attitudes, and motivation among the learners. Furthermore, according to Abdel Halim and Muhd Harun (2011), methodology of teaching Arabic employed in Malaysia still does not be able to improve this skill and it needs to be reviewed by a committee of higher learning education.

\section{Research Objectives}

This project will focus specifically on designing and developing a prototype of interactive Arabic writing tool (INWRITE), which could enhance learners' self-motivation, especially for non-Arabic speakers, and develop their language skills as follows:

(a) Problems of teaching and learning Arabic among non-Arabic speakers, especially in writing skills;

(b) The need to design and develop a special courseware for teaching and learning Arabic among non-Arabic speakers, especially in writing skills;

(c) To motivate learners of non-Arabic speakers in learning Arabic by using an interactive multimedia courseware that enhances writing skills.

The existence of multimedia courseware that enhances writing skills is still limited compared to others. 
For example, Microsoft Word Processor, which is available in English and Arabic, is an automated proofing tool that will correct the grammatical and structure errors of phrases and sentences. But the available tool only suggests several options of correct sentences without any specific justifications. The existing proofing tool in Microsoft Word is shown in Figure 1.

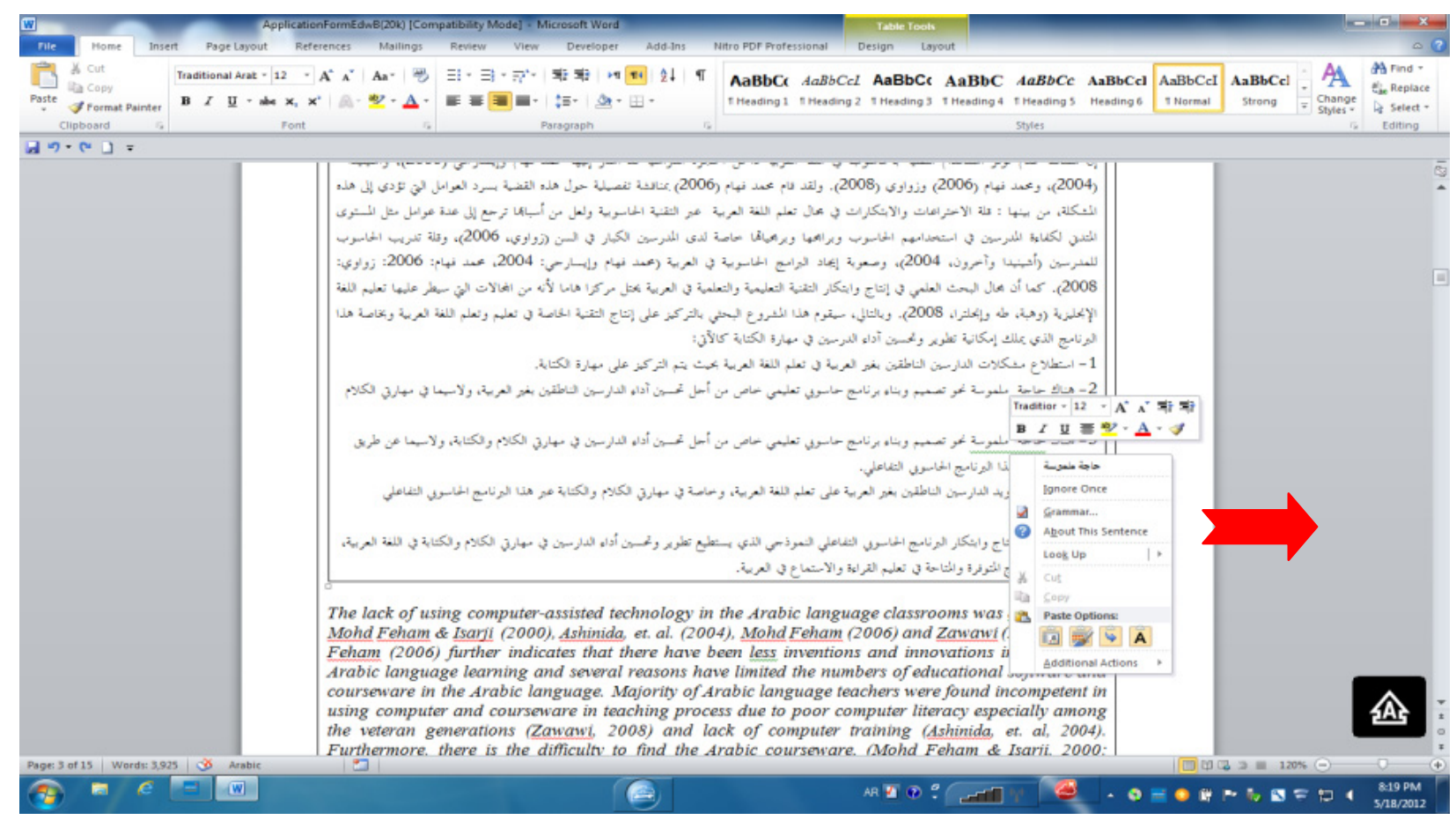

Figure 1. Auto proofing tool in Microsoft Word.

This new development will be specifically concerned on improving Arabic writing skills among non-native speakers as well giving them justifications, which will allow learners to identify errors through active trial and exploration. The sample students will be selected from the Department of Arabic Language and Literature within Year 1 and Year 2. The tool will be enhanced with extra features, such as correcting any phrases and sentences by showing the justifications of errors based on various aspects: morphology, grammar, and semantics.

\section{Research Methodology}

The methodology will be determined based on the following phases as follows:

(a) Investigating learners' problems in Arabic writing skills;

(b) Formulating the design principles that need to be catered in designing a special Arabic writing system among learners of non-Arabic speakers of IIUM;

(c) Developing a specific learning prototype to enhance learners' writing skills in Arabic by understanding the language errors and justification of corrections;

(d) Conducting several sessions of trying-out the prototype for further improvement;

(e) Applying for patent of intellectual properties and commercialization from related bodies and ministries.

The design and development model will be based on ADDIE (i.e., Analysis, Design, Development, Implement, and Evaluate) instructional design model, as shown in Figure 2. 


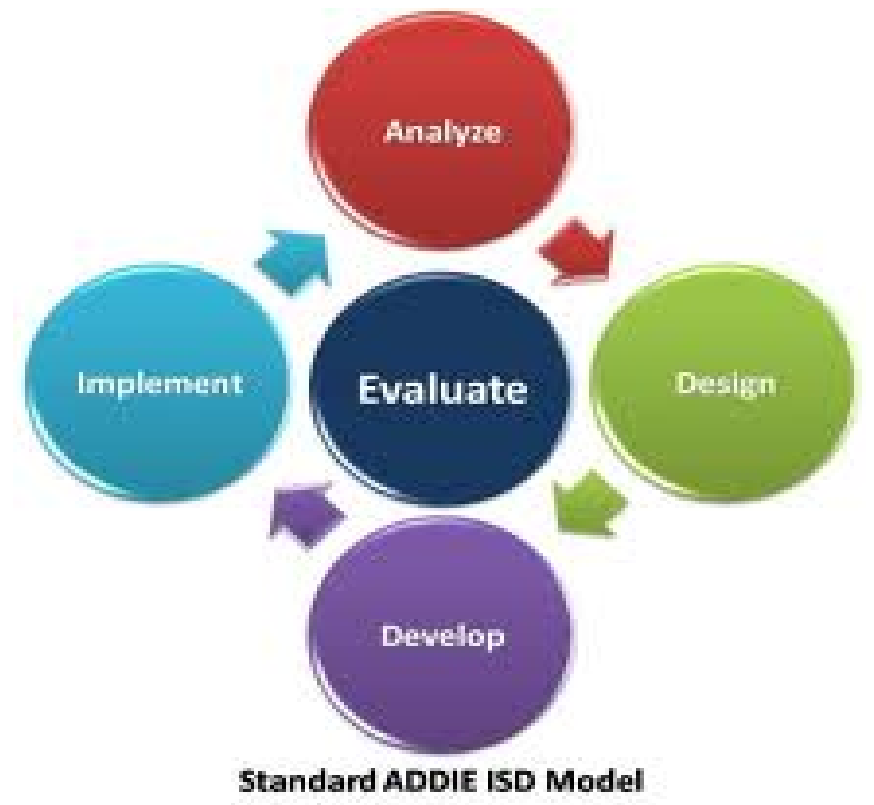

Figure 2. Research phases based on the ADDIE model.

\section{Phases of Design and Development of Modaqqeeq Sarfiy}

\section{Conducting Language Error Analysis (July-September 2013)}

An analysis of morphological and grammatical errors has been conducted among students at the first phase. The research population was selected from 24 students who were taking ARAB 2124 in the first semester, 2013/2014 between September 2013 and February 2014. The researcher has requested each of them to write a one-page article related to computer-assisted language learning in the Arabic language. After that, analysis was conducted to investigate the frequency and type of language errors found in their articles.

The results of language errors are shown in Table 1.

Table 1

Sample of Language Errors in Writing Among Students

\begin{tabular}{|c|c|c|}
\hline Language errors & Sample of language errors & Correction \\
\hline الصفة والموصوف & 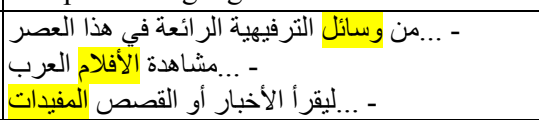 & 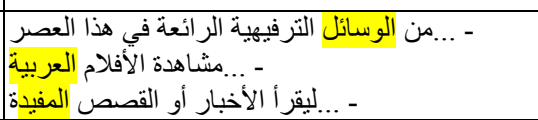 \\
\hline $\begin{array}{l}\text { اسم الموصول واسم الإشارة } \\
\text { (Connective pronouns and demonstrative } \\
\text { pronouns) }\end{array}$ & 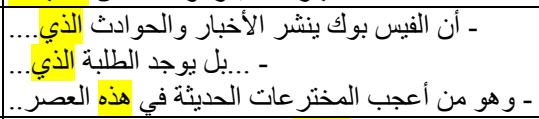 & 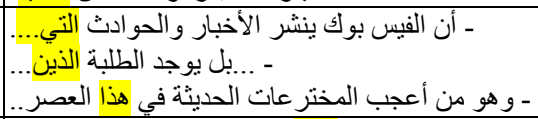 \\
\hline 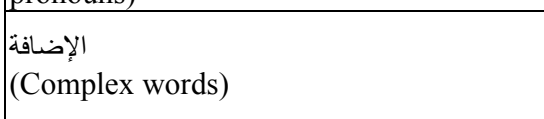 & 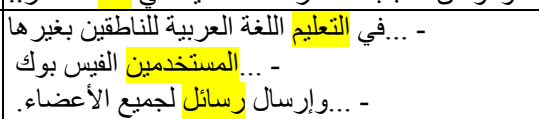 & 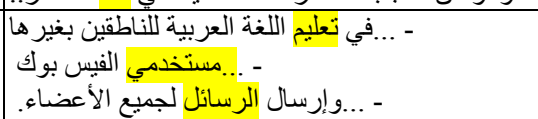 \\
\hline $\begin{array}{l}\text { تذكير وتأنيث الأفعال و عدم مطابقتها مع الفاعل } \\
\text { (Mistakes in the use of gender in verbs) }\end{array}$ & 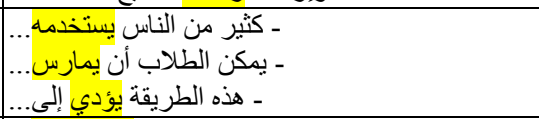 & ـ ـ ـثكن من الطلاب أن يماس ئخدمونه.... \\
\hline $\begin{array}{l}\text { كتابة همزتي القطع الوصل وعدم التفريق بينهما (Dictation errors in writing hamzah } \\
\text { (Dl-wasl and hamzah al-qata') } \\
\text { al-watal }\end{array}$ & 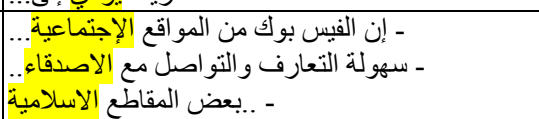 & 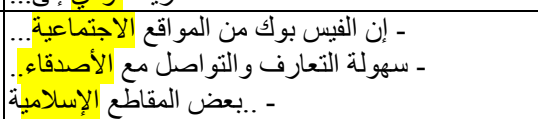 \\
\hline $\begin{array}{l}\text { تهيئة الكلمات } \\
\text { (Words spelling) }\end{array}$ & 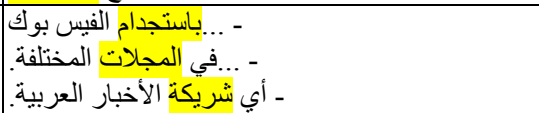 & 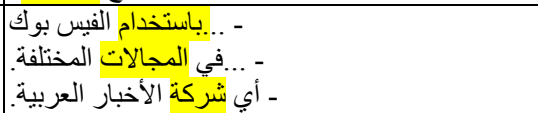 \\
\hline
\end{tabular}


(Table 1 to be continued)

\begin{tabular}{|c|c|c|}
\hline 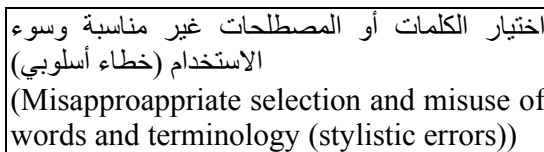 & 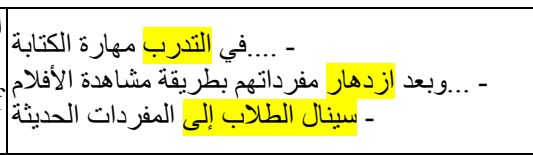 & 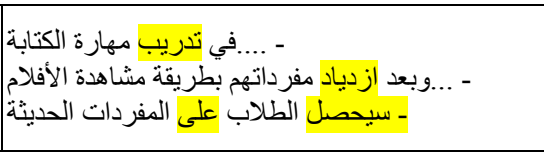 \\
\hline $\begin{array}{l}\text { بناء الأفعال واستعمال حرف الجر (خطاء صرفي) (Word structure (morphological errors) } \\
\text { (Wo the use of preposition) }\end{array}$ & يمكن أن نقر أ الأخبار أو المجلات العالمية والمحلية & - ـ يمكن أن نقر أ الأخبار أو المجلات العالمية و المحلية \\
\hline
\end{tabular}

The frequency results of language errors among the students are shown in Table 2.

Table 2

The Frequency Results of Language Errors Among the Students

\begin{tabular}{|c|c|c|c|c|}
\hline Student No. & Grammar & Morphology & Spelling & Style \\
\hline 1 & 8 & 8 & 8 & 8 \\
\hline 2 & 8 & 2 & 3 & 19 \\
\hline 3 & 12 & 2 & 0 & 5 \\
\hline 4 & 7 & 0 & 2 & 6 \\
\hline 5 & 5 & 1 & 7 & 6 \\
\hline 6 & 4 & 0 & 10 & 2 \\
\hline 7 & 5 & 1 & 18 & 2 \\
\hline 8 & 12 & 2 & 4 & 4 \\
\hline 9 & 29 & 2 & 14 & 10 \\
\hline 10 & 9 & 0 & 3 & 3 \\
\hline 11 & 5 & 5 & 11 & 7 \\
\hline 12 & 6 & 1 & 5 & 4 \\
\hline 13 & 6 & 2 & 2 & 6 \\
\hline 14 & 3 & 4 & 6 & 2 \\
\hline 15 & 5 & 0 & 3 & 1 \\
\hline 16 & 7 & 0 & 2 & 8 \\
\hline 17 & 4 & 6 & 21 & 10 \\
\hline 18 & 10 & 1 & 6 & 9 \\
\hline 19 & 8 & 1 & 4 & 5 \\
\hline 20 & 5 & 1 & 0 & 1 \\
\hline 21 & 5 & 1 & 4 & 4 \\
\hline 22 & 11 & 0 & 3 & 5 \\
\hline 23 & 16 & 1 & 1 & 6 \\
\hline 24 & 11 & 2 & 1 & 4 \\
\hline Total & $201(38.7 \%)$ & $43(8.3 \%)$ & $138(26.6 \%)$ & $137(26.4 \%)$ \\
\hline Overall total & $519(100 \%)$ & & & \\
\hline
\end{tabular}

\section{Design and Development (October-December 2013)}

Initial design of Modaqqeed ${ }^{\circledR}$ checker for enhancing Arabic writing skills. The idea of working on using fonts, computerized doing some corrections in linguistic spelling in a special way, has been adopted in the wording code on some of the rules of spelling which appeared in Arabic books, as well as research and literature that dealt with common spelling errors, such as the books The Spelling and Punctuation in Arabic Writing by Prof. Abdel-Alim Abraham, The Methods of Operation for the Treatment of Spelling Errors by Prof. Rashid bin Mohammed al-Shalan, Learning and Teaching Spelling by Nayef, and others. The things that make 
this method yield considerable, flexible programming, which can increase in those rules and improve them, and add or delete them simply, which improves the performance of this line in the identification of spelling errors and punctuation, as well as linguistic common errors. This method can contribute to solving the problem of corresponding processors spelling and language that can amended in the texts directly; since the idea here is that we know the user what mistakes offset when writing text language of Arabic, and what are the rules of sound, language errors have decreased gradually. It is also the cooperation of auditors or auditors linguists in a statement places some of the errors that can pass on the eye, during the review and correction.

Initial characteristics of Modaqqeed ${ }^{\circledR}$ checker. The initial characteristics of Modaqqeed $^{\circledR}$ checker include cases that represent some of the common mistakes in spelling writing, spelling and computer, as well as some other linguistic signals, such as the followings:

(a) Checker for dictation, such as spelling of Hamzah and Tanween;

(b) Checker for syntax;

(c) Checker for morphology.

How to use the Modaqqeed ${ }^{\mathbb{B}}$ checker? Modus operandi of the this program is shown below:

(a) Placing the font file in the Fonts folder of the operating system;

(b) Trying to write some words that contain misspellings of the previous categories and see the result;

(c) Then, the line does not make amendments to the text, it will show wrong with placements caused by pop-up comments of corrections.

Samples of corrective feedback in Modaqqeeq Sarfiy. A sample of corrective feedback in Modaqqeeq Sarfiy is shown in Figure 3.

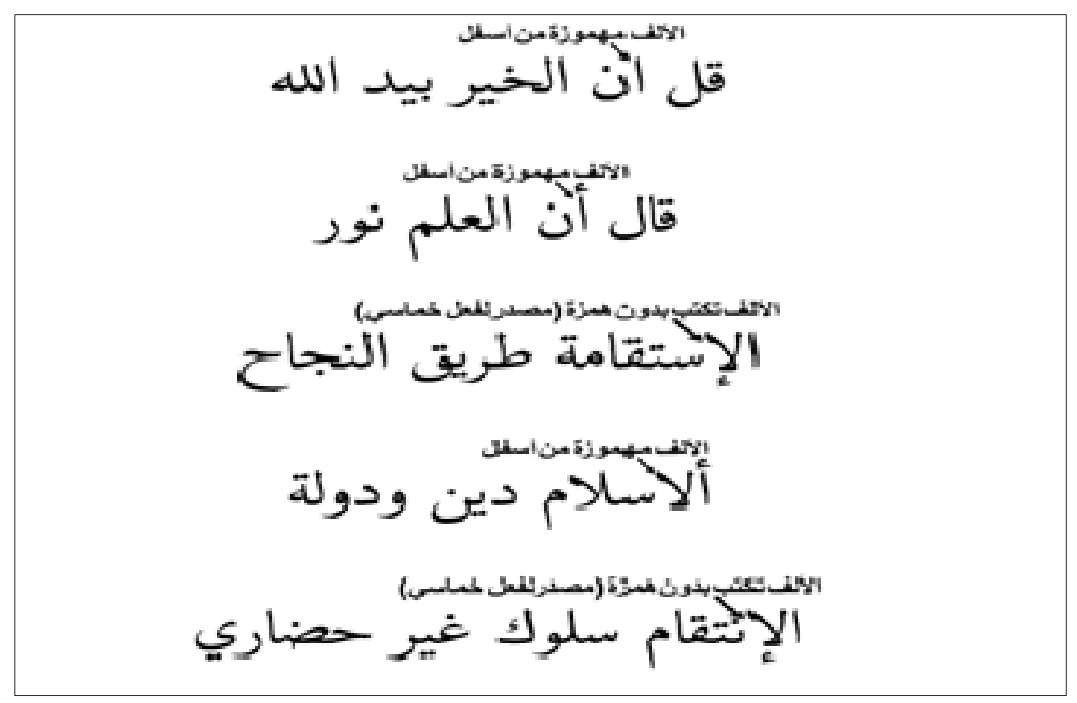

Figure 3. Corrective feedback in Modaqqeeq Sarfiy.

\section{Implementation and Evaluation (January-June 2014)}

User testing session for the first prototype. The researcher and several lecturers have used this first prototype (Modaqqeeq Sarfiy) and they found that some errors of spelling mistakes were mot detected. Thus, this prototype has been resent to the company of prototype design to reproduce the second prototype. The latest version of this prototype is known as Modaqqeeq Kitaby.

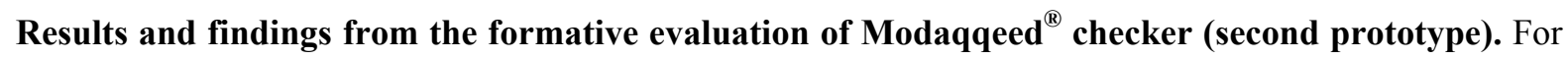


the formative evaluation of this improved prototype, 32 students who are taking the course of ARAB 2124 of the second semester of the academic year 2013-2014 were selected to evaluate this prototype.

Students' background. The background of students for this formative evaluation is shown in Table 3.

Table 3

Students' Background $(N=32)$

\begin{tabular}{llc}
\hline \multirow{2}{*}{ Gender } & Male & $7(21.9 \%)$ \\
& Female & $25(78.1 \%)$ \\
\hline \multirow{2}{*}{ Grade } & First year students & $24(75 \%)$ \\
& Second year students & $8(25 \%)$ \\
\hline \multirow{2}{*}{ Origin } & Malaysians & $29(91 \%)$ \\
& Thai & $1(3 \%)$ \\
& Singapore & $2(6 \%)$ \\
\hline
\end{tabular}

With reference to Table 3 , it can be found that the number of female students $(N=25 ; 78.1 \%)$ is more than that of the male students $(N=7 ; 21.9 \%)$. The students were between 20 and 24 years old and they were divided into first and second years students. Most of them are Malaysians except one student with Thai nationality and two students from Singapore.

Characteristics of the program and performance. The students were asked about the characteristics and performance for this prototype. The survey was conducted by the online mode via Google Survey through the link: https://docs.google.com/forms/d/1Ow_K5chowe8bLw_yg-DUXO25ZnagD5-ZUhc_brUN4rg/viewform. The survey is in 5-point Likert Scale questionnaires for the characteristics and performance for this prototype and the last part consists of an open-ended survey to explore students' opinions on the strengths, weaknesses, and suggestions for further improvement.

The results and findings are shown in Table 4.

Table 4

Performance of the Spell Checker Prototype

\begin{tabular}{llll}
\hline No. & Item & Mean score & Interpretation \\
\hline 1 & Interface design is attractive. & 4.03 & High \\
2 & Font of feedback text is appropriate. & 4.10 & High \\
3 & Size of feedback text is readable. & 4.17 & High \\
4 & Graph used is attractive. & 3.73 & High \\
5 & The quality of feedback text is good. & 3.80 & High \\
6 & Colour used for feedback text is suitable. & 3.43 & High \\
7 & Color used is adequate. & 3.40 & High \\
8 & Feedback text provided is easy to understand. & 4.37 & High \\
9 & User-friendly. & 4.17 & High \\
10 & The overall performance of the application is excellent. & 3.90 & High \\
\hline
\end{tabular}

Table 4 shows that the average of the mean scores is between 3.40 and 4.37 out of 5 with the interpretation of high score according to standard criteria by Oxford (1990).

Content delivery of the program. Table 5 shows that the average of the mean scores is between 4.06 and 4.40 out of 5 with the interpretation of high score according to standard criteria by Oxford (1990). The interpretation of mean scores in this research is done based on Oxford (1990), as shown in Table 6. 
Table 5

Content Delivery of the Spell Checker Prototype

\begin{tabular}{llll}
\hline No. & Item & Mean score & Interpretation \\
\hline 1 & Content of the feedback text is related to the morphological error. & 4.19 & High \\
2 & This application is relevant for improving students' morphological errors. & 4.32 & High \\
3 & The feedback text is easy to understand. & 4.40 & High \\
4 & The feedback text delivers most of the information you expected to learn. & 4.27 & High \\
5 & The feedback text explains the corrections and concepts very well. & 4.32 & High \\
6 & The feedback text shown is clear. & 4.10 & High \\
7 & Feedback text provided for every morphological error is adequate. & 4.06 & High \\
8 & The content of the module helps me to understand the topic very well. & 4.10 & High \\
9 & The content of this application achieves the objective of self-learning. & 4.13 & High \\
10 & The overall performance of application is useful and beneficial. & 4.27 & High \\
11 & Delivery of the overall application is excellent. & 4.16 & High \\
\hline
\end{tabular}

Table 6

Interpretation of Scores by Oxford (1990)

\begin{tabular}{ll}
\hline Mean score & Interpretation \\
\hline $5.0-4.5$ & Very high \\
$4.4-3.5$ & High \\
$3.4-2.5$ & Average \\
$2.4-1.5$ & Low \\
$1.4-1.0$ & Very low \\
\hline
\end{tabular}

\section{Feedback From Open-ended Questions}

The students involved in this survey were also asked about the strengths, weaknesses, and further suggestions to improve this spell checker prototype.

Strengths of the programme. The students stated the strengths of the spell checker prototype as follows:

1. Students can see their morphological mistakes through this program, which means that students can correct their mistakes through the explanatory note;

2. The program helps a lot to learn Arabic and understand it well;

3. The program helps a lot in understanding the errors through morphological observations presented and perceived;

4. This program is useful for students to learn and develop writing skills.

Weaknesses of the programme. The students also discussed about the weaknesses of the programme:

1. The program needs to be developed in terms of the color and size of the font used in the feedback of the spell checker;

2. Some remarks in the spell checker still need to be corrected because they are not clear;

3. This spell checker prototype is suitable for users with an Arabic language background.

Further suggestions. The students also talked about suggestions of the programme for further improvement:

1. The program needs to be developed in terms of the color and size of the font used in the feedback of the spell checker;

2. The size of the fonts in the original texts and the size of the font used in the spell checker feedback should be differentiated. 


\section{Discussion}

In general, the study found that there is an urgent need to design such a program in order to assist students in learning the Arabic language, especially for non-native Arabic speakers. The results and findings have indicated the high mean scores, which show the obvious need and acceptance of users for this spell checker prototype in enhancing students' writing skills. Somehow, the researcher still wants to improve this prototype in order to assist Arabic learners in their four areas of language errors, as shown in the analysis phase previously.

\section{Conclusion and Recommendations}

The results of the study in general showed the overall acceptance of learners towards this spell checker prototype in learning Arabic, especially in assisting them to identify their spelling mistakes in their Arabic writing. This prototype of Modaqqeeq Sarfiy is suggested to be further enhanced for different levels of language errors in spelling, morphology, grammar, and semantic. This product will contribute to the explosion of information and communication technology (ICT) in Arabic language teaching and learning among digital generations in the world.

Based on the findings of this study, the following recommendations can be made:

1. A more advanced prototype in enhancing learners' writing skills in four areas of language errors needs to be designed;

2. There is a need to design new technologies as a means to enhance Arabic teaching and learning for non-native speakers in their four language skills;

3. Experts, researchers, and lecturers in the field of Arabic language teaching should be encouraged to explore creatively and innovatively in the development of educational material and learning aids, which motivate the students towards continuous and self-centered learning;

4. Cooperation between educational institutions and companies should be established in funding the projects in order to support the development of advanced teaching and learning aids, particularly in the field of Arabic language;

5. A program for language error analysis for other devices needs to be designed, such as smartphones or mobile devices, in order to enhance student performance in Arabic language learning.

\section{References}

Abdel Halim, M., \& Muhd Harun, H. (2011). Writing proficiency among national university graduates in Malaysia: A study from the perspective of Arabic language lecturers. Paper presented at The World Conference in Teaching Arabic: Hopes and Challenges in Malaysia and China. (In Arabic)

Abdul Bari, M. S. (2010). Writing skills from origination to teaching (1st ed.). Amman, Jordan: Dar El-Masirah House of Publishing, Distribution and Printing. (In Arabic)

Ahmad, W., Rusli, W., \& Mat Daud, N. (2011). Developing Arabic writing skills using Facebook. Retrieved July 10, 2012, from http://irep.iium.edu.my/4187/1/facebook_arabic_writing.pdf

Ahmed Mukhtar, I. S. (2006). Learning Arabic through World Wide Web (1st ed.). Kuala Lumpur: Research Center, International Islamic University Malaysia. (In Arabic)

Ahmed Mukhtar, I. S., \& Mohd Feham, M. G. (2007). Computer assisted language learning: Scholars and efforts (1st ed.). Kuala Lumpur: Research Center, International Islamic University Malaysia. (In Arabic)

Aladdin, A., Hamat, A., \& Yusof, M. S. (2004). The use of computer assisted language learning in teaching and learning Arabic as a foreign language: An initial survey. GEMA Online Journal of Language Studies, 4(1), 1-16. (In Malay) 
Alessi, S. M., \& Trollip, S. R. (2001). Multimedia for learning, methods and development (3rd ed.). Boston, M.A.: Pearson Education Company.

Bygate, M. (1987). Speaking. Oxford: Oxford University Press.

El-Khuliy, A. A. K. (2004). Written expression and methods of teaching (3rd ed.). Amman, Jordan: Dar El-Masirah House of Publishing, Distribution and Printing. (In Arabic)

El-Khuliy, M. A. (1989). Arabic language teaching methods. Riyadh, Saudi Arabia: Al-Falah Foundation of Publishing, Distribution and Printing. (In Arabic)

Flagg, B. N. (1990). Formative evaluation for educational technologies. Hillsdale, N.J.: Lawrence Erlbaum Associates, Inc..

Mahmoud, A. R. A., Sahrir, M. S., \& Osman, R. A. H. (2013). Integration of an interactive program in learning Arabic language for non-natives peakers via virtual tutor. GEMA Online Journal of Language Studies, 13(3), 117-131.

Majdi, I., \& Rosli, M. H. (2011, December 5-6). Towards improving the Arab writing expression among Malaysian students. Paper presented at The International Seminar for Teaching Arabic Language, Faculty of Arabic Language, Beijing Foreign Studies University, Beijing, China. (In Arabic)

Md. Saad, R., Ismail, Z., \& Wan Abdullah, W. N. (2005). Teaching and learning Arabic via website. Retrieved June 17, 2012, from http://www.ipbl.edu.my/BM/penyelidikan/seminarpapers/2005/rahimiUM.pdf (In Malay)

Mohd Feham, M. G. (2006). The design, development and testing on the eficacy of a pedagogical agent on the performance and program rating scores among students learning Arabic (Unpublished doctoral dissertation, Universiti Sains Malaysia).

Mohd Feham, M. G., \& Isarji, S. (2000). On-line Arabic: Challenges, limitations and recommendations. Proceedings of The National Conference on Teaching and Learning in Higher Education (pp. 231-239), Universiti Utara Malaysia, Kedah.

Nashwan, Y. H. (1993). Singular education between theory and practice (1st ed.). Amman, Jordan: Dar El-Masirah House of Publishing, Distribution and Printing. (In Arabic)

Norasikin, F. (2009). Aplikasi teknik graph view dalam pemvisualan maklumat sanad domain ilmu Hadis (Application of graph view techniques for visualizing information of sanad in domain science of Hadith) (Unpublished Ph.D. dissertation, Universiti Kebangsaan Malaysia, Bangi).

Nurkhamimi, Z. (2009). Teaching and learning of writing skills among students of non specialization in Arabic language via Internet: A case in Wiki (experimental and evaluation study) (Unpublished master's thesis, International Islamic University Malaysia) (In Arabic)

Nurkhamimi, Z., Mohd Feham, M. G., \& Sahrir, M. S. (2011). Steps and procedures of teaching writing skill via Wiki among learners of Arabic as second language as a model. Journal of Linguistic and Literary Studies, 9, 325-341.

Osman, N. A. (2009). Learning reading skill via online site for non-Arabic speakers (Unpublished master's thesis, International Islamic University Malaysia). (In Arabic)

Oxford, R. L. (1990). Language learning strategies: What every teacher should know (p. 291). Boston, M.A.: Heinle \& Heinle Publisher.

Reiser, A., \& Dempsey, J. V. (2006). Trend and issues in instructional design and technology (p. 19). Upper Saddle River, N.J.: Prentice Hall.

Ribhi, M. A., \& Abdel el-Dabbas, M. (2003). Mass communication and educational technology (2nd ed.). Amman, Jordan: Dar El-Masirah House of Publishing, Distribution and Printing. (In Arabic)

Richey, R. C., \& Klein, J. D. (2007). Design and development research. Hillsdale, N.J.: Lawrence Erlbaum Associates, Inc..

Rosli, M. H. (2007). An analysis of stylistic errors in the Arabic writing expression among Malaysian high school students. (Unpublished master's thesis, International Islamic University Malaysia). (In Arabic)

Sahrir, M. S., \& Alias, N. A. (2011). A study on Malaysian language learners' perception towards learning Arabic via online games. GEMA Online Journal of Language Studies, 11(3), 129-145.

Sahrir, M. S., \& Ghazali, Y. (2012). Online vocabulary games for teaching and learning Arabic. GEMA Online Journal of Language Studies, 12(3), 961-977.

Sahrir, M. S., \& Nor Aziah, A. (2011). A study on Malaysian language learners' perception towards learning Arabic via online games. GEMA Online Journal of Language Studies, 11(3), 129-145.

Sahrir, M. S., \& Yusri, G. (2012). Online vocabulary games for teaching and learning Arabic. GEMA Online Journal of Language Studies, 12(3), 961-977.

Samah, R. (2012, May). Construction of Arabic sentences among school leavers in religious secondary schools. GEMA Online Journal of Language Studies, 12(2), 555-569. (In Malay) 
Sardi, J. (2009). Learning communicative Arabic grammar by using Web-based multimedia applications (Ph.D. dissertation Universiti Malaya, Kuala Lumpur, Malaysia). (In Malay)

Tessmer, M. (1993). Planning and conducting formative evaluations: Improving the quality of education and training. London: Kogan Page Limited.

Tinggari, S. M. (2011). Issues in Arabic language teaching and learning (1st ed.). Kuala Lumpur: International Islamic University Malaysia. (In Arabic)

Tu'aimah, R. A. (1989). Teaching Arabic to non-native speakers. Rabat, Morocco: Islamic Educational, Scientific and Cultural Organization (ISESCO). (In Arabic)

Wahba, K. M. A.,Taha, Z., \& England, L. (2006). Handbook for Arabic language teaching professionals in the 21st centuries. London: Lawrence Erlbaum Associates, Publishers.

Yahaya, M. F., Sahrir, M. S., \& Nasir, M. S. (2013). Pembangunan laman Web Ez-Arabic sebagai alternatif baru dalam pembelajaran Bahasa Arab peringkat sekolah rendah (Website development Ez-Arabic as an alternative virtual learning Arabic for primary school Malaysia). Jurnal Teknologi, 61(1), 11-18. (In Malay)

Zawawi, I. (2008). Evaluation on the implementation of curriculum of speaking skill in arabic communicative subjects in religious secondary schools (Unpublished Ph.D. dissertation, Universiti Kebangsaan Malaysia, Bangi). 